\title{
Economics of BRAC credit operation in Mymensingh district of Bangladesh
}

\author{
J. Khan, M. R. U. Mian ${ }^{1}$ and A. H. M. S. Islam ${ }^{2}$ \\ Department of Business Administration, Pundra University of Science and Technology, Bogra, Bangladesh \\ ${ }^{1}$ Department of Agricultural Finance, Bangladesh Agricultural University, Mymensingh-2202, Bangladesh \\ ${ }^{2}$ Department of Agricultural Economics, Bangladesh Agricultural University, Mymensingh-2202, Bangladesh
}

\begin{abstract}
BRAC borrowers received 100 percent credit of their applied amount. Maximum of the credit money was utilized purposively and rickshaw pulling borrowers showed the highest purposive utilization. All the borrowers satisfactorily repaid their loan within the specified term. The important factors for timely loan repayment were found to be self awareness, installment mode of payment and group pressure. Borrower's income proved to be the most significant factor contributing repayment process. Grocery shop borrowers experienced the highest increase in income and expenditure while rickshaw pulling borrowers experienced the same in saving. Though BRAC credit brought positive change to its borrowers, the impact was not satisfactory. So, other related programs with credit support were suggested to bring desired change for the borrowers.
\end{abstract}

Keywords: Credit, Adequacy, Utilization, Repayment and Impact

\section{Introduction}

Bangladesh is the most densely populated country of the world. More than 42 percent of the people are still living below the poverty line where agriculture contributes the highest of 21.91 percent in total GDP of the country (BBS, 2005). One of the major reasons for low productivity and wide spread poverty of Bangladesh is lack of access to productive assets and financial resources by the poor. Most of the poor people of the country have no saving; even sometimes they have negative saving. So they are not able to go for big investment due to scarcity of working capital. It is possible to fill up their needs by extending credit facilities and it can bring desirable change that ultimately would contribute to the socioeconomic improvement of the poor and economic development of the country. To provide more institutional credit facilities to the poor, there are a good number of credit institutions at present in the country including Bangladesh Rural Advancement Committee (BRAC).

Micro finance program has been given utmost emphasis as a tool for poverty alleviation across the world since last two decades. Obviously Bangladesh has registered a tremendous success in implementing micro finance program amongst the poor people with a view to reducing poverty which started in early seventies. In fact, micro finance is getting more priority even in national economic activities of different countries.

The last decade witnessed an explosion in both number and scale of organizations providing micro credit to poor people to help them escape from poverty. But lending procedure, target group and rate of interest are not the same for all these institutions which influence micro credit program run in the country (Alam, 2005). There are also regional variations among the operations of same organization. The BRAC is one of the largest NGOs in Bangladesh (BRAC, 2004). So, its credit operation certainly bears importance for detailed investigation to know the NGO financing in Bangladesh. Thus an attempt has been made in this endeavor to know the economics of BRAC credit operation including adequacy, utilization, repayment and impact which would benefit policy makers, academicians, credit agencies and their beneficiaries in the country.

\section{Materials and Methods}

Two villages namely Bhabkhali and Kewatkhali under Mymensingh sadar were purposively selected for the study. These villages are under the jurisdiction of BRAC Churkhai branch. Forty BRAC member households were randomly selected from the villages under study. Survey method was followed to collect necessary information during the period from August to September 2006. BRAC borrowers were found to be engaged them in different income generating activities (IGAs). Among them three mostly practiced IGAs, i.e., grocery shop, tea stall and rickshaw pulling were considered for the study. 
The collected information was analyzed with descriptive statistics like percentage, frequency counts, mean and standard deviation. The specific regression model (Gujarati, 2003) used to assess the factors affecting repayment performance of the borrowers is as follows:

$Y=a+b_{1} X_{1}+b_{2} X_{2}+b_{3} X_{3}+b_{4} X_{4}+b_{5} X_{5}+b_{6} X_{6}+e_{i}$

Where, $Y=$ amount of loan repaid (Tk), $X_{1}=$ age of the respondent (years), $X_{2}=$ borrower's education (years of schooling), $X_{3}=$ borrower's income $(T k), X_{4}=$ amount of loan received $(T k), X_{5}=$ borrower's saving (Tk), $e_{i}=$ error term and $b_{1}, b_{6}=$ regression coefficients of the respective independent variables.

\section{Results and Discussion}

Adequacy of credit as required by the respondents: Capital is required for investment in different IGAs. To meet this requirement, credit is helpful as it creates scope for further investment. The demand for credit of a person depends to a greater extent on his economic condition as well as on type and scale of activities in which he is engaged. It is very difficult to compare credit adequacy and credit requirement of different enterprises because of their different levels of practice in production activities. Adequacy of credit was measured by the percentage of loan received as compared to the amount applied for by the respondents. Table 1 shows that the borrowers received 100 percent of the amount applied for. This is because the BRAC personnel consult with the borrowers about their requirement before sanctioning the loan. So the borrowers received entire of their applied amount and tendency of showing excess amount in application was avoided easily.

Table 1. Adequacy of BRAC credit

\begin{tabular}{|c|c|c|c|}
\hline IGAs & $\begin{array}{c}\text { Average amount } \\
\text { applied for (TK) }\end{array}$ & $\begin{array}{c}\text { Average amount } \\
\text { received (Tk) }\end{array}$ & $\begin{array}{c}\text { Amount received as \% } \\
\text { of applied for }\end{array}$ \\
\hline Grocery shop & 6800.00 & 6800.00 & 100 \\
\hline Tea stall & 6767.00 & 6767.00 & 100 \\
\hline Rickshaw pulling & 4800.00 & 4800.00 & 100 \\
\hline All (average) & 6122.33 & 6122.33 & 100 \\
\hline
\end{tabular}

IGAs: Income Generating Activities

Source: Field Survey, 2006

Utilization of credit by the respondents: Credit plays a significant role in increasing family income and consumption if it is properly utilized. Proper utilization of credit is a prerequisite to attain aim and target of both credit disbursement and receipt as well as for growth of income. The BRAC loanees in general were observed to have utilized more than 93 percent of the loaned money purposively during the year while only about 7 percent of the same have been utilized for unreported purposes (Table 2). Average amount of credit received was Tk 6122.33 percent whereas amount utilized was Tk 5722.33. The amount utilized for tea stall was the highest (97.04 percent). The following figures were rickshaw pulling and grocery shop constituting 95.83 and 88.24 percent, respectively. So, the loan utilization capacity of the BRAC borrowers in the study area was satisfactory.

Table 2. Credit utilization by the respondents

\begin{tabular}{|c|c|c|c|c|c|}
\hline IGAs & \multirow{2}{*}{$\begin{array}{c}\text { Amount } \\
\text { received } \\
(\text { Tk) }\end{array}$} & \multicolumn{2}{|c|}{$\begin{array}{c}\text { Amount utilized for reported } \\
\text { purpose }\end{array}$} & \multicolumn{2}{c|}{$\begin{array}{c}\text { Amount utilized for other } \\
\text { purpose }\end{array}$} \\
\cline { 3 - 6 } & Tk & $\%$ & Tk & $\%$ \\
\hline Grocery shop & 6800.00 & 6000.00 & 88.24 & 800.00 & 11.67 \\
\hline Tea stall & 6767.00 & 6567.00 & 97.04 & 200.00 & 2.96 \\
\hline Rickshaw pulling & 4800.00 & 4600.00 & 95.83 & 200.00 & 4.17 \\
\hline All (average) & 6122.33 & 5722.33 & 93.47 & 400.00 & 6.53 \\
\hline
\end{tabular}

IGAs: Income Generating Activities

Source: Field Survey, 2006 
Repayment of BRAC credit by the respondents: Repayment capacity is one of the crucial aspects of credit analysis. It is mostly related to the effective utilization. Use of credit for unproductive purposes very often results in overdue of loans and weakens the financial viability of the financial institutions (Mian and Kasem, 2006). The success of credit institutions, therefore, depends mostly on the extent of proper utilization of credit supplied to the borrowers. The mode of loan repayment of BRAC was on weekly basis and the total amount of loan along with interest was to be repaid in 46 equal installments. Table 3 represents that the borrowers of BRAC under all IGAs repaid their loaned money by 100 percent including principal and interest. So, the repayment performance was fully satisfactory for the BRAC micro credit program in the study area. All the borrowers used 46 weekly installments to repay their loan.

Table 3. Repayment of credit by the respondents

\begin{tabular}{|c|c|c|c|c|c|c|}
\hline \multirow[t]{2}{*}{ IGAs } & \multicolumn{3}{|c|}{ Average amount to be repaid (Tk) } & \multirow{2}{*}{$\begin{array}{c}\text { Average } \\
\text { amount repaid } \\
\text { (Tk) }\end{array}$} & \multirow{2}{*}{$\begin{array}{c}\% \text { of } \\
\text { repayment }\end{array}$} & \multirow{2}{*}{$\begin{array}{c}\text { No. of } \\
\text { installment } \\
\text { used (No.) }\end{array}$} \\
\hline & $\begin{array}{c}\text { Principal } \\
(T k)\end{array}$ & $\begin{array}{c}\text { Interest @ } \\
20 \% \text { (Tk) }\end{array}$ & $\begin{array}{l}\text { Total } \\
\text { (Tk) }\end{array}$ & & & \\
\hline Grocery shop & 6800.00 & 1360.00 & 8160.00 & 8160.00 & 100 & 46 \\
\hline Tea stall & 6767.00 & 1353.40 & 8120.40 & 8120.40 & 100 & 46 \\
\hline Rickshaw pulling & 4800.00 & 960.00 & 5760.00 & 5760.00 & 100 & 46 \\
\hline All (average) & 6122.33 & 1224.47 & 7346.80 & 7346.80 & 100 & 46 \\
\hline
\end{tabular}

IGAs: Income Generating Activities

Source: Field Survey, 2006

Factors affecting loan repayment by the borrowers: The respondents were asked to express the reasons which inspired them to repay the credit installments regularly. Tabular as well as regression analyses had been done to identify the factors affecting the loan repayment performance. Table 4 depicts that self awareness (90 percent), pressure of other group members (80 percent) and easy to pay by installment (75 percent) were the most effective factors for loan repayment. The other factors were proper supervision by the BRAC field workers and hope of further loan as reported by 72.50 percent each of the beneficiaries during the study year. So, self awareness, installment mode and group pressure were the main factors influencing satisfactory loan repayment of BRAC in the study area.

Table 4. Factors affecting loan repayment

\begin{tabular}{|l|c|c|c|c|c|c|c|c|}
\hline \multirow{2}{*}{ Factors } & \multicolumn{9}{c|}{ Respondents and IGAs } \\
\cline { 2 - 8 } & \multicolumn{2}{|c|}{ Grocery shop } & \multicolumn{2}{c|}{ Tea stall } & \multicolumn{2}{c|}{$\begin{array}{c}\text { Rickshaw } \\
\text { pulling }\end{array}$} & \multicolumn{4}{c|}{ All } \\
\cline { 2 - 9 } & No. & $\%$ & No. & $\%$ & No. & $\%$ & No. & $\%$ \\
\hline Hope of further loan & 11 & 27.50 & 9 & 22.50 & 9 & 22.50 & 29 & 72.50 \\
\hline Self awareness & 14 & 35.00 & 14 & 35.00 & 8 & 20.00 & 36 & 90.00 \\
\hline Proper supervision by field workers & 10 & 25.00 & 11 & 27.50 & 8 & 20.00 & 29 & 72.50 \\
\hline Pressure of group members & 13 & 32.50 & 12 & 30.00 & 7 & 17.50 & 32 & 80.00 \\
\hline Persuasion by branch manager & 6 & 15.00 & 4 & 10.00 & 5 & 12.50 & 15 & 37.50 \\
\hline Easy to pay by installment & 11 & 27.50 & 12 & 30.00 & 7 & 17.50 & 30 & 75.00 \\
\hline Having more income by using loan & 10 & 25.00 & 8 & 20.00 & 5 & 12.50 & 23 & 57.50 \\
\hline
\end{tabular}

IGAs: Income Generating Activities

Source: Field Survey, 2006

The results of regression analysis containing contributions of different factors in satisfactory repayment are summarized in Table 5 . It is evident from the table that except age other factors significantly contributed the repayment performance. Again, except loan amount other factors positively affected the repayment. It indicates that keeping other things constant 1 percent increase in borrower's education, income and saving would enhance repayment by $0.027,1.117$ and 0.320 percent, respectively. The co-efficient of loan amount was negative which might be the cause of under or unproductive utilization if loan is sanctioned in excess of required amount. Among the factors, borrower's income was the most effective (significant at 1 percent level) contributing satisfactory loan repayment. 
The value of $R^{2}$ indicates that explanatory variables explained 87 percent of the total variation of loan repayment by BRAC respondents during the year under study. F-value was highly significant. It reveals that all the explanatory variables were important to explain the variation in loan repayment.

Table 5. Estimated values of co-efficients contributing loan repayment

\begin{tabular}{|l|c|c|}
\hline \multicolumn{1}{|c|}{ Explanatory variables } & Estimated values & $t$-values \\
\hline $\mathrm{X}_{1}$ (age of the respondent) & 0.026 & -0.46 \\
\hline $\mathrm{X}_{2}$ (borrower's education) & $0.027^{* *+}$ & 1.86 \\
\hline $\mathrm{X}_{3}$ (borrower's income) & $1.117^{*}$ & 3.66 \\
\hline $\mathrm{X}_{4}$ (amount received) & $-0.320^{*}$ & -3.15 \\
\hline $\mathrm{X}_{5}$ (borrower's saving) & $0.320^{* *}$ & 2.19 \\
\hline Value of $\mathrm{R}^{2}$ & 0.87 & - \\
\hline Value of $\mathrm{F}$ & 52.92 & - \\
\hline
\end{tabular}

* significant at $1 \%$ level

** significant at $5 \%$ level

*** significant at $10 \%$ level

Source: Field Survey, 2006

Impact of BRAC credit on socioeconomic conditions of the borrowers: It was endeavored to know the impact of BRAC credit on beneficiaries in the study area. Table 6 indicates that by using BRAC credit annual income increased to the highest of 18.95 percent to the grocery shop borrowers followed by tea stall (10.85 percent) and rickshaw pulling (9.99 percent) borrowers. The highest expenditure increase was also evident in grocery shop borrowers (14.40 percent) but it was followed by rickshaw pulling (12.51 percent) and tea stall (9.77 percent) borrowers. In the case of saving rickshaw pullers experienced the highest increase (9.85 percent) followed by grocery shop keepers (9.40 percent) and tea stallers (9.36 percent). On an average the borrowers' income, expenditure and saving were increased by $13.15,12.20$ and 9.53 percent respectively. So, it is clear that BRAC credit became able to enhance income, expenditure and saving situations of the borrowers in the study area.

Table 6. Impact on annual income, expenditure and saving

\begin{tabular}{|c|c|c|c|c|}
\hline IGAS & $\begin{array}{c}\text { Before } \\
\text { (Tk) }\end{array}$ & $\begin{array}{l}\text { After } \\
\text { (Tk) }\end{array}$ & $\begin{array}{c}\text { Net change } \\
(T k)\end{array}$ & $\begin{array}{c}\text { Change } \\
(\%)\end{array}$ \\
\hline \multicolumn{5}{|c|}{ Impact on annual income } \\
\hline Grocery shop & 58560.33 & 69655.33 & 11095.00 & 18.95 \\
\hline Tea stall & 65440.00 & 72540.00 & 7100.00 & 10.85 \\
\hline Rickshaw pulling & 60062.00 & 66063.00 & 6001.00 & 9.99 \\
\hline All (average) & 61354.11 & 69419.44 & 8065.33 & 13.15 \\
\hline \multicolumn{5}{|c|}{ Impact on annual expenditure } \\
\hline Grocery shop & 50503.50 & 57773.57 & 7270.07 & 14.40 \\
\hline Tea stall & 52100.00 & 57191.07 & 5091.07 & 9.77 \\
\hline Rickshaw pulling & 50300.00 & 56592.78 & 6292.78 & 12.51 \\
\hline All (average) & 50967.83 & 57185.81 & 6217.98 & 12.20 \\
\hline \multicolumn{5}{|c|}{ Impact on annual saving } \\
\hline Grocery shop & 64300.00 & 70345.00 & 6045.00 & 9.40 \\
\hline Tea stall & 66545.00 & 72771.43 & 6226.43 & 9.36 \\
\hline Rickshaw pulling & 61040.20 & 67054.44 & 6014.24 & 9.85 \\
\hline All (average) & 63961.73 & 70056.96 & 6095.22 & 9.53 \\
\hline
\end{tabular}

IGAs: Income Generating Activities

Source: Field Survey, 2006 
The respondents were asked to investigate the impact of BRAC credit on their socioeconomic conditions. Responses thus collected are furnished in Table 7 in terms of 'no change', 'small change' and 'medium change'. No respondent replied 'high change' in terms of their socioeconomic uplift. The table reveals that maximum of the borrower experienced small socioeconomic change after being borrowers of BRAC in the study area. Among small changes, awareness building and improvement in clothing were the highest (each of 62.50 percent). The only highest medium change was the increased family income which was reported by 52.50 percent of the respondents. So, it can be said that though BRAC credit increased family income it is yet to bring favorable changes in other socioeconomic conditions of the beneficiaries in the study area.

Table 7. Socioeconomic impact of BRAC credit

\begin{tabular}{|l|c|c|c|c|c|c|c|c|}
\hline \multirow{2}{*}{$\begin{array}{c}\text { Fields of socioeconomic } \\
\text { change }\end{array}$} & \multicolumn{2}{|c|}{ No change } & \multicolumn{2}{c|}{ Small change } & \multicolumn{2}{c|}{ Medium change } & \multicolumn{2}{c|}{ Total } \\
\cline { 2 - 10 } & No. & $\%$ & No. & $\%$ & No. & $\%$ & No. & $\%$ \\
\hline Awareness building & 5 & 12.50 & 25 & 62.50 & 10 & 25.00 & 40 & 100 \\
\hline Scope of family education & 6 & 15.00 & 24 & 60.00 & 10 & 25.00 & 40 & 100 \\
\hline Increased family income & 4 & 10.00 & 15 & 37.50 & 21 & 52.50 & 40 & 100 \\
\hline Improvement in clothing & 5 & 12.50 & 25 & 62.50 & 10 & 25.00 & 40 & 100 \\
\hline Improving social status & 25 & 62.50 & 8 & 20.00 & 7 & 18.00 & 40 & 100 \\
\hline Family saving & 8 & 20.00 & 24 & 60.00 & 8 & 20.00 & 40 & 100 \\
\hline $\begin{array}{l}\text { Adaptation of family } \\
\text { planning measures }\end{array}$ & 10 & 25.00 & 15 & 37.50 & 10 & 25.00 & 40 & 100 \\
\hline Using sanitary latrine & 10 & 25.00 & 15 & 37.50 & 15 & 37.50 & 40 & 100 \\
\hline
\end{tabular}

Source: Field Survey, 2006

\section{Conclusion}

BRAC disburse credit after assuring the credit requirement of the borrower carefully. So, the borrowers received 100 percent of their applied amount. Again, due to proper supervision borrowers used maximum of credit money (93.47 percent) for productive purposes. As productive utilization is ensured, loan repayment performance of the borrowers was fully satisfactory (100 percent). Weekly installment, self awareness and group pressure were the most influential factors for the borrowers to repay their loan timely. On the other hand income, education and saving are the variables contributing significantly in the repayment process. All the borrowers experienced increase in income, expenditure and saving after taking BRAC credit for their IGAs. Increase in income and expenditure was the highest for grocery shop keepers while rickshaw pullers achieved the highest increase in saving. Though BRAC credit brought positive impact for the borrowers, the responses of the borrowers were almost 'small change' in nature. So, BRAC should incorporate other support services with its credit program for satisfactory enhancement of the borrowers. The other development organizations of the country should consider this matter in their development policies to make their development strategies effective and successful.

\section{References}

Alam, A.B.M.N. 2005. Rural Women in Micro-credit Programs for Poverty Alleviation- a Study of BRAC in Sadar Upazila of Netrokona District. M.S. Thesis, Department of Agricultural Finance, Bangladesh Agricultural University, Mymensingh-2202, Bangladesh.

BBS. 2005. Statistical Yearbook of Bangladesh. Bangladesh Bureau of Statistics, Ministry of Planning, Government of the People's Republic of Bangladesh, Dhaka.

BRAC. 2004. Annual Report. Bangladesh Rural Advancement Committee, Dhaka, Bangladesh.

Gujarati, N.D. 2003. Basic Econometrics. McGraw Hill (4 ${ }^{\text {th }}$ edition), NY, 10020.

Mian, M.R.U. and Kasem, M.A. 2006. Effectiveness of RAKUB Crop Credit in Selected Areas of Rangpur District. Journal of the Bangladesh Agricultural University, Vol. 4, No. 1. 